
2. To: (Receiving Organization)
Distribution
5. Proj./Prog./Dept./Div.:
SNF Project/W-4.41

8. Originator Remarks:

For approval and release.
4. Related EDT No::

NA

7. Purchase Order No.:

NA

9. Equip./Component No.:

NA

10. System/Bidg./Facility:

CVDE/ $14.2 \mathrm{~K}$

12. Major Assm. Dwg. No.:

NA

13. Permit/Permit Application No.: NA

14. Required Response Date:

KEY

\begin{tabular}{|c|c|c|c|c|c|c|c|c|}
\hline 15. & & DATA TR & NSMITTE & & (F) & (G) & (H) & (l) \\
\hline $\begin{array}{l}\text { (A) } \\
\text { Item } \\
\text { No. }\end{array}$ & (B) Document/Drawing No. & $\begin{array}{l}\text { (C) Sheet } \\
\text { No. }\end{array}$ & (D) Rev. & (E) Title or Description of Data Transmitted & $\begin{array}{l}\text { Approval } \\
\text { Desig- } \\
\text { nator }\end{array}$ & $\begin{array}{l}\text { Reason } \\
\text { for Trans- } \\
\text { mittal }\end{array}$ & $\begin{array}{c}\text { Origi- } \\
\text { nator } \\
\text { Dispo- } \\
\text { stion }\end{array}$ & $\begin{array}{c}\text { Receiv- } \\
\text { er } \\
\text { Dispo- } \\
\text { sition }\end{array}$ \\
\hline 1 & SNF-3061 & A.11 & 0 & CVDE Civil/Structural SDD & NA & 2 & 1 & \\
\hline 2 & SNE-3.066 & Al] & 0 & CVDF Compressed Air SDD & NA & 2 & 1 & 0 \\
\hline 3 & $-3 N F-3067$ & $A+1$ & & EVPE GS-HeIIUM SDD & $\mathrm{NA}-$ & -2 & 1 & \\
\hline 4 & $S N E-3072$ & Al1 & 0 & CVDF Crane SDD & NA. & 2 & 1 & \\
\hline 5 & $S N E-3073$ & All & 0 & CVDF Effluent Drain SDD & NA & 2 & 1 & \\
\hline 6 & SNE-3074 & A11 & 0 & CVDF Condensate SDD & NA & 2 & 1 & \\
\hline 7 & SNE-3077 & All & 0 & CVDF Eire Protection SDD & NA & 2 & 1 & \\
\hline
\end{tabular}

16.

Reason for Transmittal (G)

\begin{tabular}{|c|l|}
\hline Approval Designator (F) & \\
\hline E, S, Q, D OR N/A & 1. Approval \\
(See WHC-CM-3-5, & 2. Release \\
Sec. 12.7) & 3. information
\end{tabular}

17.

\begin{tabular}{|c|c|c|}
\hline $\begin{array}{l}\text { (G) } \\
\text { Rea- } \\
\text { son }\end{array}$ & $\begin{array}{l}(\mathrm{H}) \\
\text { Disp. }\end{array}$ & $\begin{array}{ll}\text { (K) Signature } & \text { (L) Date } \quad(M) M S I N\end{array}$ \\
\hline \multirow[t]{2}{*}{1} & l & Design Authority C.C. Pitkoff \\
\hline & & Design Agent \\
\hline 1 & 1 & 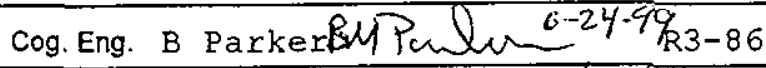 \\
\hline 1 & I & Cog. Mgr. C.s. Haller CMAlec/28/2/R3-86 \\
\hline 3 & & QA S.I. Mischke \\
\hline 3 & & J.R. Brehm \\
\hline & & Env. \\
\hline
\end{tabular}

$$
\text { 西 }
$$

cC Prtkoff

S-A. Pr. Bristiat

Signature of EDT

Signature of
Originator

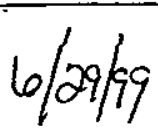

Date
Disposition (H) \& (I)
4. Review

5. Post-Review

6. Dist. (Receipt Acknow. Required)

\begin{tabular}{|ll|}
\hline \multicolumn{1}{|c|}{ Disposition $(\mathrm{H})$ \& (I) } \\
\begin{tabular}{ll} 
1. Approved & 4. Reviewed no/comment \\
2. Approved w/comment & 5. Reviewed w/comment \\
3. Disapproved w/comment & 6. Receipt acknowledged \\
\hline
\end{tabular}
\end{tabular}
SIGNATURE/DISTRIBUTION

(See Approval Designator for required signatures)
(Sequil

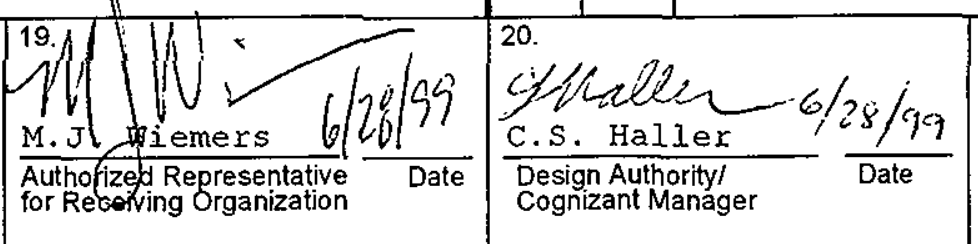

Authofized Representative for Resolving Organization \begin{tabular}{c|c|l}
$\begin{array}{c}\text { (G) } \\
\text { Rea- }\end{array}$ & $(\mathrm{H})$ & (J) Name
\end{tabular} Rea- Disp.
son
(K) Signature

(L) Date

(M) MSIN
21. DOE APPROVAL (if required)

Ctrl No. NA

Approved

Approved w/comments

Disapproved w/comments 


\title{
Cold Vacuum Drying Facility Personnel Monitoring System Design Description
}

\author{
C. C. Pitkoff \\ DE\&S Hanford, \\ Richland, WA 99352 \\ U.S. Department of Energy Contract DE-AC06-96RL13200
}

\author{
EDT/ECN: 626308 \\ UC: 510 \\ Org Code: $2 \mathrm{~F} 800$ \\ CACN: 105568 \\ COA: A000 \\ B\&R Code: 39EW70400 \\ Total Pages: 42
}

Key Words: SNF, CVD, W-441, design description, instrument air, compressed air

Abstract: This document describes the Cold Vacuum Drying Facility (CVDF) instrument air (IA) system that provides instrument quality air to the CVDF. The IA system provides the instrument quality air used in the process, HVAC, and HVAC instruments. The IA system provides the process skids with air to aid in the purging of the annulus of the transport cask. The IA system provides air for the solenoid-operated valves and damper position controls for isolation, volume, and backdraft in the HVAC system. The IA system provides air for monitoring and control of the HVAC system, process instruments, gas-operated valves, and solenoid-operated instruments. The IA system also delivers air for operating hand tools in each of the process bays.

TRADEMARK DISCLAIMER. Reference herein to any specific commercial product, process, or service by trade name, trademark. manufacturer, or otherwise, does not necessarily constitute or imply its endorsement. recommendation. or favoring by the United States Government or any agency thereof or its contractors or subcontractors.

Printed in the United States of America. To obtain copies of this document, contact: Document Control Services, P.0. Box 950. Mailstop H6-08, Richland WA 99352, Phone (509) 372-2420: Fax (509) 376-4989.
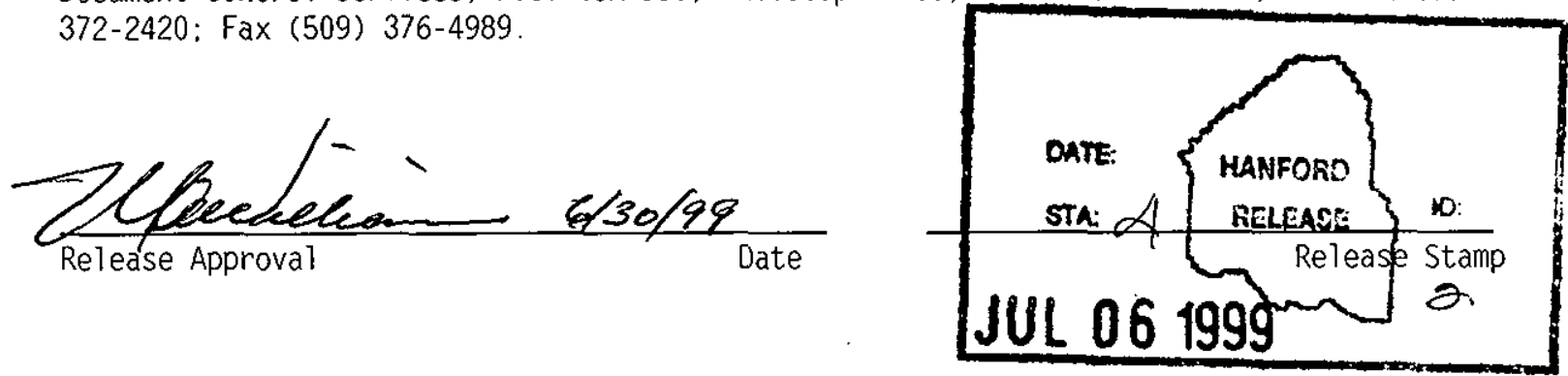

\section{Approved for Public Release}


SNF-3066 Rev. 0

\section{COLD VACUUM DRYING FACILITY}

INSTRUMENT AIR SYSTEM

DESIGN DESCRIPTION

SYSTEM 12 


\section{TABLE OF CONTENTS}

1.0 INTRODUCTION

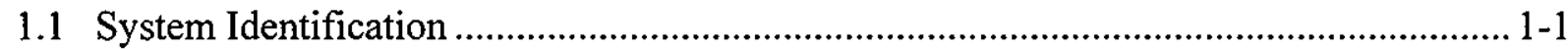

1.2 Limitations of This SDD........................................................................................

1.3 Ownership of This SDD ......................................................................................1-1

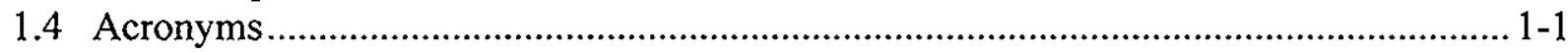

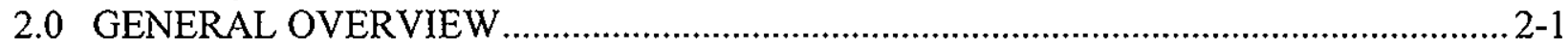

2.1 System Functions ....................................................................................................... 2-1

2.1.1 Normal Process Functions ……............................................................................. 2-1

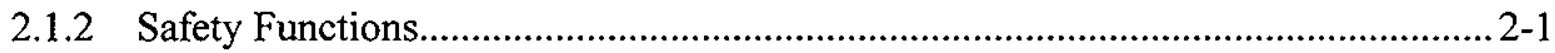

2.2 System Classification.................................................................................................22-1

2.3 Basic Operational Overview …….............................................................................. 2-1

2.3.1 Basic Design Overview........................................................................................ 2-2

2.3.2 Basic Operational Overview ……...................................................................... 2-2

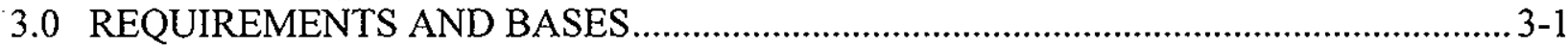

3.1 General Requirements............................................................................................ $3-1$

3.1.1 System Functional Requirements ....................................................................... 3-1

3.1.2 Subsystem and Major Components .................................................................... 3-3

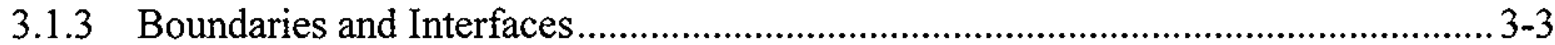

3.1.4 Codes, Standards, and Regulations ................................................................... 3-3

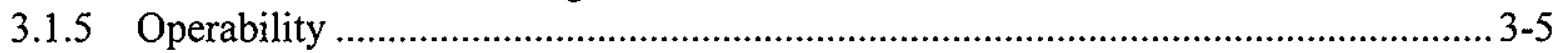

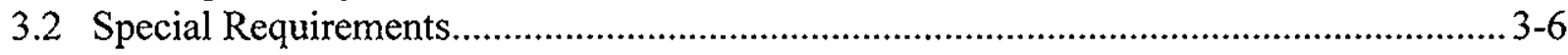

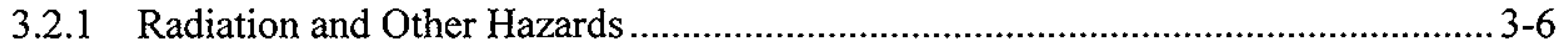

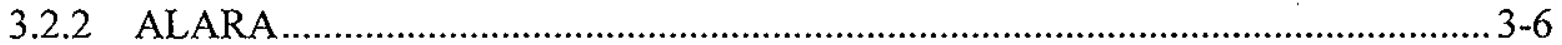

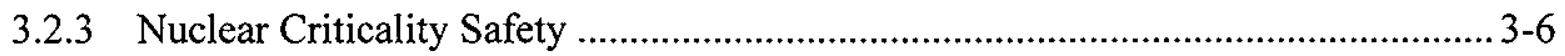

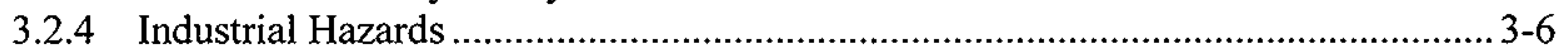

3.2.5 Operating Environment and Natural Phenomena ................................................... 3-6

3.2.6 Human Interface Requirements ........................................................................ 3-6

3.2.7 Specific Commitments...................................................................................... 3-6

3.3 Engineering Disciplinary Requirements ................................................................. 3-6

3.3.1 Civil and Structural ......................................................................................... 3-7

3.3.2 Mechanical and Materials ...............................................................................

3.3.3 Chemical and Process .................................................................................... 3-7

3.3.4 Electrical Power ............................................................................................. 3-7

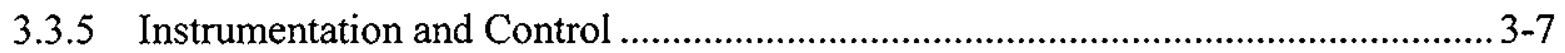

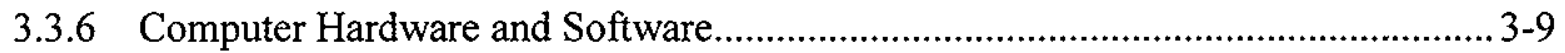

3.3.7 Fire Protection.................................................................................................... 3-9

3.4 Testing And Maintenance Requirements .................................................................. 3-9

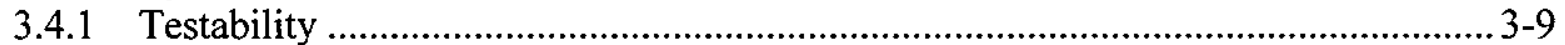

3.4.2 Technical Safety Requirement Required Surveillances.......................................3-9

3.4.3 Non-Technical Safety Requirement Inspections and Testing ............................... 3-10

3.4.4 Maintenance ........................................................................................................ 3-10

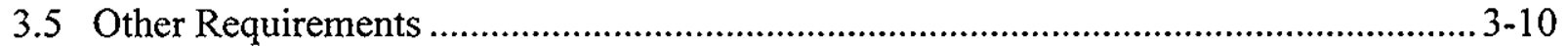

3.5.1 Security and Special Nuclear Material Protection .................................................. 3-10 
3.5.2 Special Installation Requirements................................................................ 3-10

3.5.3 Reliability, Availability, and Preferred Failure Modes..........................................3-10

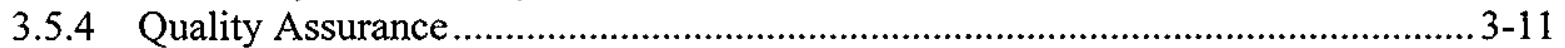

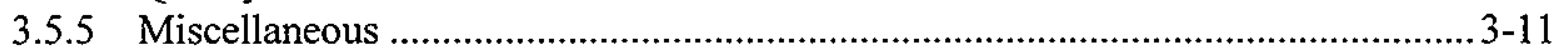

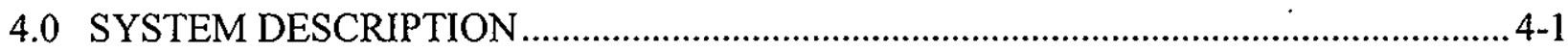

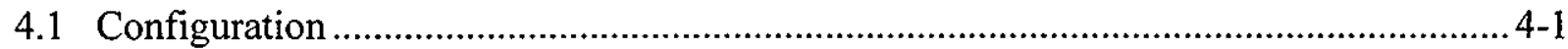

4.1.1 Description of System, Subsystems, and Major Components .................................. 4-1

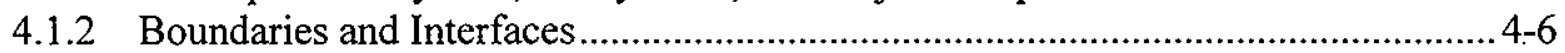

4.1.3 Physical Location and Layout................................................................................. 4-7

4.1.4 Principles of Operation ................................................................................ 4-7

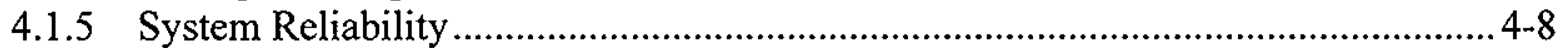

4.1.6 System Control Features ..................................................................................... 4-9

4.2 Operations ........................................................................................................... 4-9

4.2.1 Initial Configurations (Pre-startup) ..................................................................... 4-9

4.2.2 System Startup ....................................................................................... 4-10

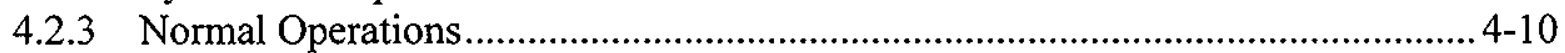

4.2.4 Off-Normal Operations..........................................................................................

4.2.5 System Shutdown ........................................................................................ 4-10

4.2.6 Safety Management Programs and Administrative Controls................................ 4-10

4.3 Testing And Maintenance ...................................................................................... 4-10

4.3.1 Temporary Configurations................................................................................ 4-10

4.3.2 Technical Safety Requirement-Required Surveillances ....................................... 4-10

4.3.3 Non- Technical Safety Requirement Inspections, and Testing ............................. 4-10

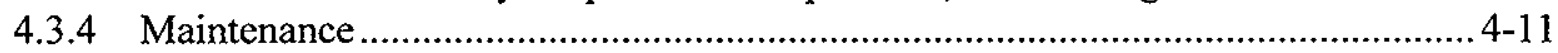

4.3.5 Equipment Calibration ......................................................................................... 4-11

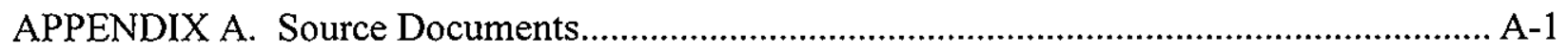

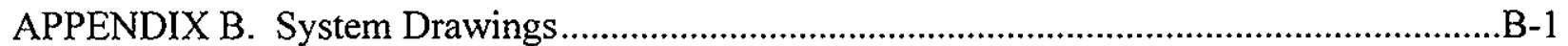

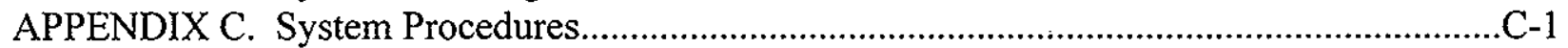


SNF-3066 Rev. 0

\section{LIST OF FIGURES}

Figure 1-1. Instrument Air System .............................................................................. 1-3

Figure 2-1. General Layout of Instrument Air System ............................................................... 2-3

Figure 4-1. General Layout of Instrument Air System ............................................................. 4-3

Figure 4-2. Compressor and Drying System...................................................................... 4-4

Figure 4-3. Distribution System.......................................................................................... 


\subsection{INTRODUCTION}

\subsection{System Identification}

This system design description (SDD) addresses the instrument air (IA) system that provides instrument quality air to the Cold Vacuum Drying Facility (CVDF). The IA system supports the operation of the heating, ventilation, and air conditioning (HVAC) system, the process equipment skids, and process instruments in the CVDF. The following discussion is limited to the compressor, dryer, piping, and valving that provide the IA as shown in Drawings H-1-82222, Cold Vacuum Drying Facility Mechanical Utilities Compressed \& Instrument Air P\&ID, and H1-82161, Cold Vacuum Drying Facility Process Equipment Skid P\&ID MCO/Cask Interface. Figure 1-1 shows the physical location of the IA system in the CVDF.

\subsection{Limitations of This SDD}

This SDD is developed in accordance with the following documents and noted revisions:

- $\quad$ Safety Analysis Report (SNF-3553, Annex B), Rev 0

- $\quad$ Project design requirements (HNF-SD-SNF-DRD-002), Rev 4

- $\quad$ Fire Hazard Analysis (HNF-SD-SNF-FHA-003), Rev 0

- $\quad$ Master Equipment List (SNF- 4148), Rev 0A

- $\quad$ Data and calculation matrix tracking list (SNF-3001), Rev 0

- Construction Specification for Project W-441, Section 15400, Plumbing/Piping.

\subsection{Ownership of This SDD}

The cold vacuum drying design authority assigned to the IA system is responsible for the accuracy and technical content of this SDD. Any questions on the system or content of this document shall be resolved through the design authority.

\subsection{Acronyms}

$\begin{array}{ll}\text { ANSI } & \text { American National Standards Institute } \\ \text { ASME } & \text { American Society of Mechanical Engineers } \\ \text { CFR } & \text { Code of Federal Regulations } \\ \text { CVDF } & \text { Cold Vacuum Drying Facility } \\ \text { DOE } & \text { U.S. Department of Energy } \\ \text { DRD } & \text { design requirements document } \\ \text { gal } & \text { gallon } \\ \text { gpm } & \text { gallons per minute } \\ \text { HVAC } & \text { heating, ventilation, and air conditioning } \\ \text { IA } & \text { instrument air } \\ \text { MCO } & \text { multi-canister overpack } \\ \text { MCS } & \text { monitoring and control system } \\ \text { PCV } & \text { pressure control valve }\end{array}$


SNF-3066 Rev. 0

psig pounds per square inch gauge

SAR safety analysis report

scfm cubic feet (at standard temperature and pressure) per minute

SNF spent nuclear fuel

SRV safety relief valve

TBD to be determined

$\mathrm{V}$ valve 
SNF-3066 Rev. 0

Figure 1-1. Instrument Air System

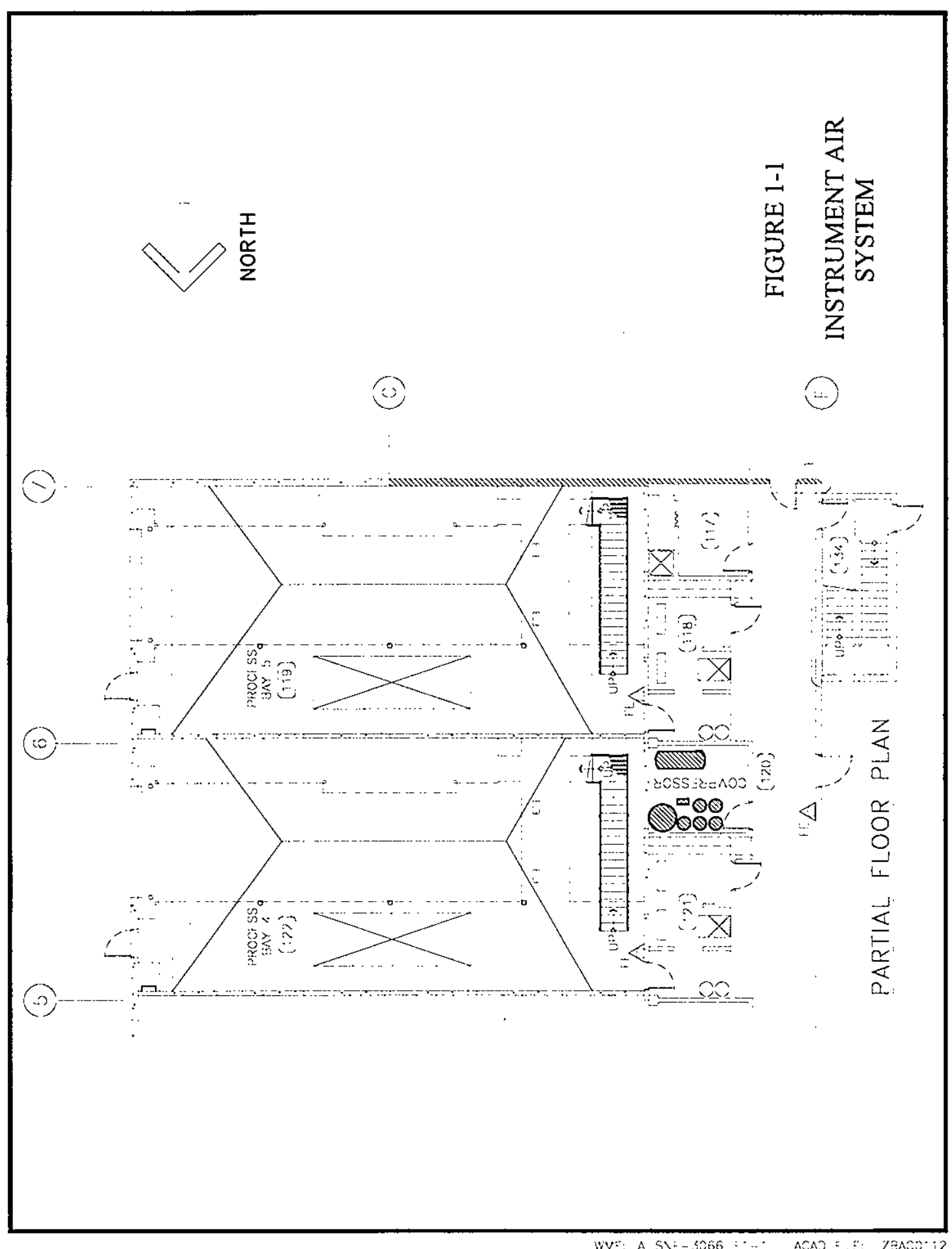


SNF-3066 Rev. 0

\subsection{GENERAL OVERVIEW}

This section provides a general overview of the IA system. Section 2.1 describes the system functions. Section 2.2 states the IA system classification and Section 2.3 outlines the basic operation of the IA.

\subsection{System Functions}

\subsubsection{Normal Process Functions}

The IA system is used to produce and distribute compressed instrument quality air throughout the CVDF. The IA system provides the IA used in the process, HVAC, and HVAC instruments. The IA system provides the process skids with air to aid in the purging of the annulus of the transport cask. The IA system provides air for the solenoid-operated valves and damper position controls for isolation, volume, and backdraft in the HVAC system. The IA system provides air for monitoring and control of the HVAC system, process instruments, gas-operated valves, and solenoid-operated instruments. The IA system also delivers air for operating hand tools in each of the process bays.

\subsubsection{Safety Functions}

The compressed air system is analyzed in HNF-3553, Chapter B3.0, to perform the following safety functions to mitigate safety-significant consequences from the bounding accident scenarios.

- $\quad$ Provide a safety-significant function of being capable of re-opening the fail-closed process hood isolation dampers when the general supply/exhaust HVAC system is not operable and the hood exhaust fans are re-started under standby power. The system's operation supports mitigation of potential radioactive releases from the CVD Facility after the gaseous release, MCO external hydrogen explosion, internal hydrogen explosion, thermal runaway reaction, and MCO overpressurization accidents. This requirement to demonstrate HVAC confinement functions for the process bays and each DBA is summarized in Table B4-8.

\subsection{System Classification}

The IA system is designated as general service.

\subsection{Basic Operational Overview}

This section briefly describes how the IA system operates. Figure 2-1 is a simplified diagram of the IA. 
SNF-3066 Rev. 0

\subsubsection{Basic Design Overview}

The IA system is run continuously and provides four hours of compressed air supply in the event of compressor downtime. The IA system consists of duplex, two-stage, piston-type compressors (CA-CMP-5019), a 250-gal receiver tank (CA-TK-5019), pressure control valve (PCV-5006), air dryer with automatic regenerative desiccant beds (CA-DRY-5020), a safety relief valve (SRV5007), a low pressure alarm (PAL-5008), a particulate pre-filter, a coalescing filter, an afterfilter, and associated distribution piping and valves. The IA is routed from room 120 to the process bays through a distribution system with valves and quick-connect connectors.

\subsubsection{Basic Operational Overview}

The IA system is used to produce and distribute compressed instrument quality air throughout the CVDF. The IA system supports the operation of the HVAC system, the process equipment skid, and process instruments in the CVDF. The IA system provides the process equipment skid with air to aid in purging the area between the multi-canister overpack (MCO) and the transport cask. 
SNF-3066 Rev. 0

Figure 2-1. General Layout of Instrument Air System

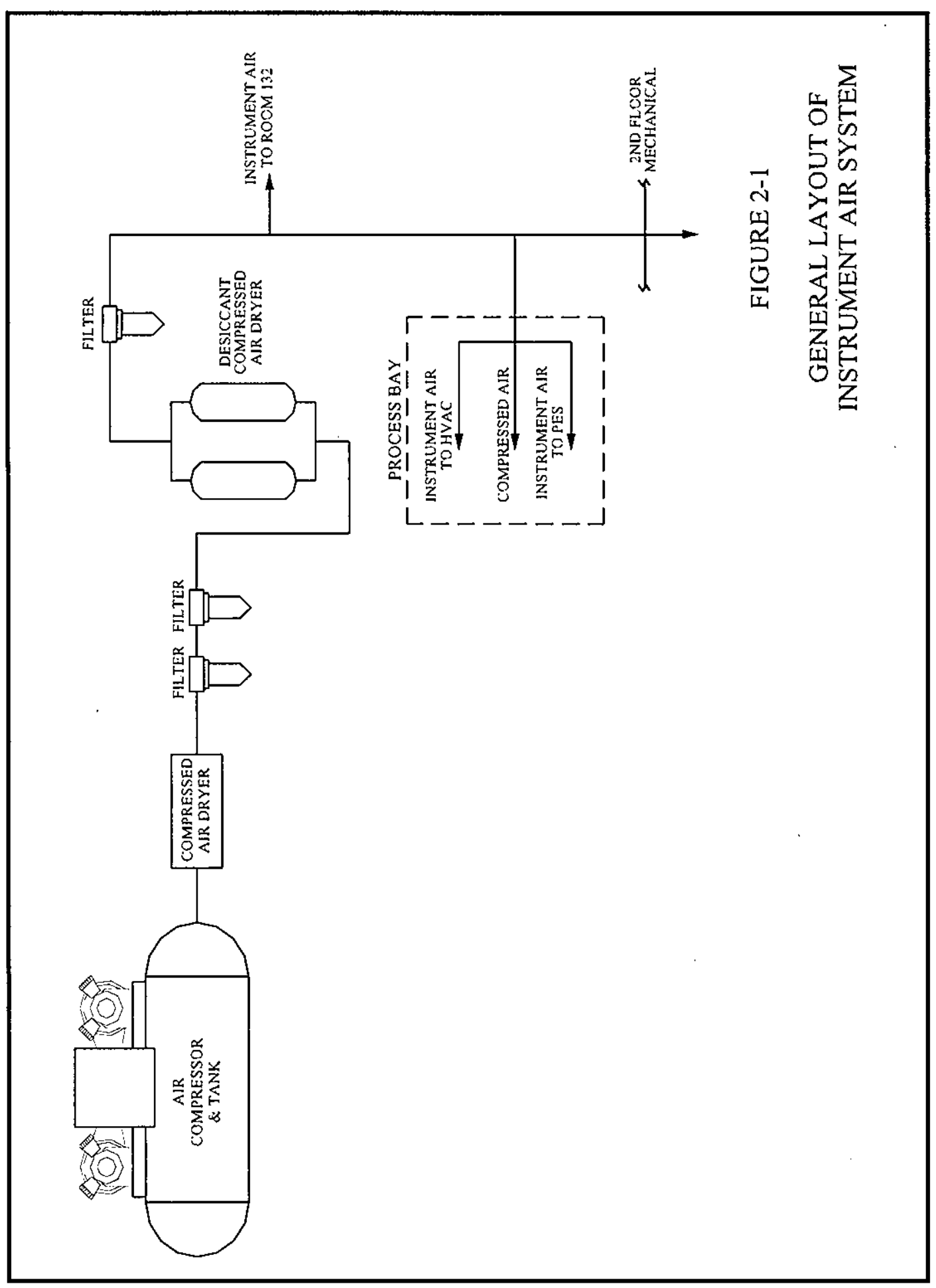

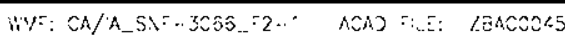




\subsection{REQUIREMENTS AND BASES}

\subsection{General Requirements}

Operational and functional requirements are taken from HNF-SD-SNF-DRD-002, Cold Vacuum Drying Facility Design Requirements, "Process System Design Requirements."

\subsubsection{System Functional Requirements}

\subsubsection{Design Requirements}

1. Requirement: The delivery rate is determined by assuming that all air-operated process valves and air-driven HVAC dampers actuate simultaneously in conjunction with the operation of a single air-driven tool.

Basis: HNF-SD-SNF-DRD-002, Section 6.6.4.7a. Sizing of the IA system ensures operation at maximum demand.

How the system meets the requirement: Calculation MER-2288-CA1 documents and analyzes the delivery rate of the IA system.

2. Requirement: The receiver tank is designed, fabricated, and stamped in accordance with the ASME code, Section VIII, and sized to supply air to activate all valves and HVAC dampers twice.

Basis: HNF-SD-SNF-DRD-002, Section 6.6.4.7b. Any pressure vessel must meet corresponding ASME code and receiver tank is sized based on operating experience.

How the system meets the requirement: The receiver tank complies with ASME code, Section VIII, and calculation MER-2288-CA1 documents and analyzes the size requirement of the receiver tank.

3. Requirement: The normal operating pressure is $100 \mathrm{psig}$.

Basis: HNF-SD-SNF-DRD-002, Section 6.6.4.7c. The air-operated valves and equipment require 100 psig.

How the system meets the requirement: The compressor was sized to deliver 100 psig (see calculation MER-2288-CA1).

4. Requirement: Instrument air is free of oil and is dried to $-37^{\circ} \mathrm{C}\left(-35^{\circ} \mathrm{F}\right)$ pressure dew point based on $100 \mathrm{psig}$ and $38^{\circ} \mathrm{C}\left(100^{\circ} \mathrm{F}\right)$ ambient. 
Basis: HNF-SD-SNF-DRD-002, Section 6.6.4.7d. IA must be oil-free and dry to prevent fouling of air-operated equipment and valves. These values are based on past operating experience.

How the system meets the requirement: IA undergoes additional drying and oil removal via filters and drying via automatic regenerative desiccant beds before being routed to the process. The IA system supplies dry, filtered, oil-free compressed air at 100 psig with a maximum dew point of $-40^{\circ} \mathrm{C}\left(-40^{\circ} \mathrm{F}\right)$.

5. Requirement: Piping is designed and constructed in accordance with ASME B31.9 (facility) or ASME B31.3 (process skids).

Basis: HNF-SD-SNF-DRD-002, Section 6.6.4.7e. Piping systems need to meet the corresponding ASME code.

How the system meets the requirement: Piping is designed and constructed in accordance with ASME B31.9 in the facility and ASME B31.3 on the process skids.

6. Requirement: Compressed air system maintenance activities or failure of one compressed air system component cannot preclude the CVD operation.

Basis: HNF-SD-SNF-DRD-002, Section 6.6.4.7f. A failure of a general service component cannot be allowed to stop operation of the CVDF.

How the system meets the requirement: The IA system delivers four hours of compressed air during maintenance or failure situations. The IA system is equipped with redundant compressors.

7. Requirement: Compressed air and IA are provided to each process bay to operate pneumatic tools, cask trailer leveling devices, and air-operated valves.

Basis: HNF-SD-SNF-DRD-002, Section 6.6.4.7f. The IA system is the only system that can provide air to the required elements in each process bay.

How the system meets the requirement: The IA system is designed to deliver IA to each process bay to operate the required equipment.

\subsubsection{Safety Requirements}

3.1.1.2.1 Safety Class Requirements. There are no safety class requirements for the IA system.

3.1.1.2.2 Safety Significant Requirements. There are no safety significant requirements for the IA system. The safety significant source of compressed air used for isolation damper HVAC-DMP- $8 * 03$ is included as part of the HVAC system and is discussed in SDD-3081. 
SNF-3066 Rev. 0

3.1.1.2.3 Other Safety Requirements. There are no other safety requirements for the IA system.

3.1.1.3 Environmental Requirements. There are no environmental requirements for the IA system.

3.1.1.4 Mission-Critical Requirements. There are no mission-critical requirements for the IA system.

\subsubsection{General Requirements.}

\subsubsection{Subsystem and Major Components}

The IA system consists of compressors, tanks, dryers, filters, valves, instrumentation, and piping that route the IA to the process equipment and instrumentation for the operation of the CVDF.

\subsubsection{Boundaries and Interfaces}

The IA system interfaces with a number of different components throughout the CVDF, but has no interface or boundary requirements identified.

\subsubsection{Codes, Standards, and Regulations}

\subsubsection{Code of Federal Regulations (CFR)}

10 CFR 830.120, "Quality Assurance"

29 CFR 1910.120, "Occupational Safety and Health Standards."

\subsubsection{American Society of Mechanical Engineers (ASME)}

B16.5, Pipe Flanges and Flanged Fittings (ANSI-approved)

B16.10, Face to Face and End to End Dimensions of Valves

B16.11, Forged Steel Fittings, Socket-Welding and Threaded (ANSI-approved)

B16.21, Nonmetallic Flat Gaskets for Pipe Flanges

B16.25, Buttwelding Ends

B16.34, Valves Flanged, Threaded, and Welding End

B16.39, Malleable Iron Threaded Pipe Unions Classes 150, 250, and 300 (ANSI-approved) 
SNF-3066 Rev. 0

B18.2.1, Square and Hex Bolts and Screws Inch Series Including Hex Cap Screws and Lag Screws (ANSI-approved)

B31.9, Process Piping Code

Boiler and Pressure Vessel Code

- $\quad$ Section II, "Material Specifications, Welding Rods, Part C Electrodes, and Filler Metals"

- $\quad$ Section VIII, "Division I Rules for Construction of Pressure Vessels"

- $\quad$ Section IX, "Qualification Standard for Welding and Brazing Procedures, Welders, Brazers, and Welding and Brazing Operators"

\subsubsection{American Society of Nondestructive Testing}

SNT-TC-1A, Recommended Practice

\subsubsection{American Society for Testing and Materials}

A36, Standard Specification for Structural Steel

A105, Standard Specification for Forgings, Carbon Steel, for Piping Components

A240, Standard Specification for Heat-Resisting Chromium and Chromium-Nickel Stainless Steel Plate, Sheet, and Strip for Pressure Vessels

A269, Standard Specification for Seamless and Welded Austenitic Stainless Steel Tubing for General Service

A276, Standard Specification for Stainless and Heat-Resisting Steel Bars and Shapes

A307, Standard Specification for Carbon Steel Bolts and Studs, 60,000 PSI Tensile Strength

A312/312M, Standard Specification for Seamless and Welded Austenitic Stainless Steel Pipes

A354, Standard Specification for Quenched and Tempered Alloy Steel Bolts, Studs and Other Externally Threaded Fasteners

A479, Standard Specification for Stainless and Heat-Resisting Steel Bars and Shapes for Use in Boilers and other Pressure Vessels

A480, Standard Specification for General Requirements for Flat-Rolled Stainless Heat-Resisting Steel Plate, Sheet, and Strip

A500, Standard Specification for Cold-Formed Welded and Seamless Carbon Steel Structural 
Tubing in Rounds and Shapes

A563, Standard Specification for Carbon and Alloy Steel Nuts

\subsubsection{American Welding Society}

AWS D1.1, Structural Welding Code-Steel

3.1.4.6 DOE Standards. All IA pumps, tanks, valves, components, instrumentation, controls, and support structures are general service items and are designed and qualified for Performance Category 1 as defined in DOE-STD-1021, Natural Phenomena Hazards Design and Evaluation Criteria for Department of Energy Facilities.

\subsubsection{National Equipment Manufacturers Association}

NEMA 250, Enclosures for Electrical Equipment

\subsubsection{National Fire Protection Association}

Not applicable.

\subsubsection{Operability}

Portions of the compressed air/instrument air system provide an independent air supply for each process hood isolation damper. Each of the system functional requirements is discussed below.

Operating Capacity. Under normal operation, the compressed air systems in each bay will receive air from the instrument air system at a pressure of $100 \mathrm{lb} / \mathrm{in}^{2}$ gauge. Design of the compressed air system is based on the air tanks having minimum capacity of $8.3 \mathrm{gal}$ at a pressure of $100 \mathrm{lb} / \mathrm{in}^{2}$ gauge to support isolation damper operation in a loss of power situation. Double check valves are installed on the inlet air supply line to the compressed air tanks to provide system isolation from general service portions of the system. This air supply capability will provide a pressure of $200 \mathrm{lb} / \mathrm{in}^{2}$ gauge. The normal operating pressure of $100 \mathrm{lb} / \mathrm{in}^{2}$ gauge provides sufficient air volume in the reservoir to complete four actuations of the isolation damper. Double check valves prevent loss of air to possible line breaks in the general service portions of the IA system and local air pressure indication is provided for the operator to monitor the tank pressure in each bay.

On loss of power, the solenoid valve will block flow of air to the actuator for the process hood isolation damper and the damper will close. When standby power is activated, the solenoid valve is energized and will reopen and air from the in-line safety significant compressed air reservoir will flow to the actuator to open the damper as required. The general service compressed air/instrument air system normally maintains pressure in the reservoirs. The reservoirs are isolated form the instrument air system by safety-significant check valves when process upsets occur, which result in loss of instrument air including loss of power. Periodic 
monitoring of the pressure in the tanks by the operators ensures capability for functional operation of the dampers upon loss of power.

\subsection{Special Requirements}

\subsubsection{Radiation and Other Hazards}

There are no radiation and other hazards requirements for the IA system.

\subsubsection{ALARA}

There are no as low as reasonably achievable (ALARA) features in the IA system.

\subsubsection{Nuclear Criticality Safety}

Criticality control is not required for the IA system.

\subsubsection{Industrial Hazards}

There are no industrial hazard requirements for the IA system.

\subsubsection{Operating Environment and Natural Phenomena}

The IA system is capable of operating in typical environmental conditions; there are no extraordinary design requirements for operating environment or natural phenomena conditions for the IA system.

\subsubsection{Human Interface Requirements}

The IA system operates in an automatic mode. Human interface is limited, but may include activation of the system, periodic surveillance, and maintenance functions.

\subsubsection{Specific Commitments}

The IA system is in compliance with the Hanford Federal Facility Agreement and Consent Order (Ecology et al. 1994), and with applicable federal, state, and local laws, and American Indian treaty rights.

\subsection{Engineering Disciplinary Requirements}


SNF-3066 Rev. 0

\subsubsection{Civil and Structural}

All IA process equipment vessels and tanks are designed and fabricated in accordance with Boiler and Pressure Vessel Code (ASME 1995), Section VIII, "Rules for Construction of Pressure Vessels," Division 1, and Heat Exchangers Mechanical Standards (Tank Equipment Manufactures Association 1992).

\subsubsection{Mechanical and Materials}

All IA process equipment piping and valves are designed and fabricated in accordance with ANSI/ASME B31.9, Process Piping Code, and ANSI/ASME B16 Standards series, Fittings, Flanges, and Valves (see Section 3.1.1.4).

\subsubsection{Chemical and Process}

There are no chemical and process requirements for this system.

\subsubsection{Electrical Power}

The electrical power supply provides normal and standby power for the IA system to operate. This system is described in SDD SNF-3075.

\subsubsection{Instrumentation and Control}

Although not required for operation, the Monitoring and Control System (MCS) provides alarm functions at several locations on the IA system.

All instrumentation and controls are designed and fabricated ANSI/ISA-S5.1, Instrument Symbols and Identification; ANSI/ISA-S5.4, Instrument Loop Diagrams; ANSI/ISA-S18.1, Annunciator Sequences and Specifications; and ANSI/ISA-S20, Specification Forms for Process Measurement and Control Instruments Primary Elements and Control Valves.

1. Requirement: Local electronic transmitters (for remote indication) include local indication whenever practical.

Basis: HNF-SD-SNF-DRD-002, Section 6.1.1.3a. Good engineering practices.

How the system meets the requirement: Local transmitters are provided whenever practical to include local indication in construction of the IA system.

2. Requirement: A local control station is provided for major electrical equipment. A switch is provided to allow for Hand (local on), OFF, and Remote (from MCS).

Basis: HNF-SD-SNF-DRD-002, Section 6.1.1.3. Good engineering practice. 
How the system meets the requirement: A local control station is provided for major electrical equipment in construction of the IA system.

3. Requirement: Engineering units are used wherever possible. The use of a zero to 100 percent range indication is avoided. The range of equipment covers the expected normal range and upset, emergency, and faulted ranges if the instrument is used under these conditions.

Basis: HNF-SD-SNF-DRD-002, Section 6.1.1.3c. Good engineering practice.

How the system meets the requirement: Instrumentation and control units use engineering units if possible as required in the construction specifications.

4. Requirement: Where possible, instruments are capable of calibration without the need to open fluid boundary. The use of wells, isolation valves, and test ports are used whenever possible.

Basis: HNF-SD-SNF-DRD-002, Section 6.1.1.3d. Good engineering practice.

How the system meets the requirement: Instruments that are capable of calibration without opening the fluid boundary are used wherever possible in construction of the IA system.

5. Requirement: Panel design considers the likelihood of surface radioactive contamination and water sprays. Panels larger than eight inches long and eight inches high use hinged door covers. For all instrument racks, the access doors are removable.

Basis: HNF-SD-SNF-DRD-002, Section 6.1.1.3e. Good engineering practice.

How the system meets the requirement: Panel are designed and constructed according to required construction specifications.

6. Requirement: The use of hardwired interlocks is appropriate to the condition being protected against. For the most part, MCS interlocks are used (software interlocks); however, for the protection of personnel or equipment that could sustain significant damage, hard interlocks are used.

Basis: HNF-SD-SNF-DRD-002, Section 6.1.1.3g. Good engineering practice.

How the system meets the requirement: Hard interlocks are used according to the appropriate condition being protected against as required in the construction specifications.

7. Requirement: Standardization of the selection of instrumentation and control equipment is critical to maintenance and cost-effectiveness. All common items within the CVDF are of the same make and model whenever possible. 
Basis: HNF-SD-SNF-DRD-002, Section 6.1.1.3h. Good engineering practice.

How the system meets the requirement: Instrumentation and control equipment are selected to ensure that common items are of the same make and model.

8. Requirement: "Emergency off" buttons are mushroom-type switches. "Emergency off" buttons are implemented where required based on the impact to personnel and equipment.

Basis: HNF-SD-SNF-DRD-002, Section 6.1.1.3i. Good engineering practice.

How the system meets the requirement: "Emergency off" buttons are provided where personnel and equipment may be impacted.

\subsubsection{Computer Hardware and Software}

General service computer hardware and software are covered under the SDD and the computer software design description for the MCS (SNF-3090).

\subsubsection{Fire Protection}

There are no fire protection requirements for this system.

\subsection{Testing And Maintenance Requirements}

\subsubsection{Testability}

Testing features are designed to implement testing requirements. System design incorporates features for verifying system operability.

\subsubsection{Technical Safety Requirement Required Surveillances}

The following assumptions associated with the compressed air system require TSRs to ensure performance of the safety function.

- $\quad$ The compressed air system in each bay must be functional whenever the process bay local HVAC exhaust and process vent system is operating in that bay.

- Leak tightness of the compressed air system piping, tank and check valve components is verified on an appropriate schedule to ensure operation if there is loss of instrument air supply.

- $\quad$ Compressed air system tank gauges are calibrated on an appropriate schedule.

- Operators periodically verify tank pressure is above $901 b / \mathrm{in}^{2}$ gauge pressure by observing the reservoir pressure gauges according to procedure. 
- Operators periodically verify tank pressure by observing the reservoir pressure gauges hourly ant time the local exhaust is operating on standby power.

\subsubsection{Non-Technical Safety Requirement Inspections and Testing}

Functional performance criteria are tested periodically to ensure operability of systems and components. All testing is performed between $\mathrm{MCO}$ processing cycles to the maximum extent possible and has minimal impact on processing availability.

System operability is verified by surveillance of the system's operability status and component states (e.g., valve position, supply pressure, system alarms) before enabling the system for each MCO process cycle. The system requires additional periodic surveillance if it is required to be operational for an extended period beyond one normal processing cycle.

The IA system has sufficient testability designed into it to permit the periodic measurement and calibration of all setpoints and adjustments that affect the manner in which the IA performs. Periodic testing of IA structures, systems, and components (SSCs) is dictated by the requirements of the individual components according to the respective manufacturer's recommended schedule and practice.

\subsubsection{Maintenance}

The design of the system took in to account the short life cycle of the facility and was designed to minimize downtime caused by regularly scheduled maintenance activities. System maintenance activities are limited to maintenance caused by failures. System design incorporates features for ease of maintenance (e.g., sufficient working space around the component for repair or removal). To the maximum extent possible, the design allows major components and energy sources to be easily isolated to meet lock and tag requirements.

\subsection{Other Requirements}

\subsubsection{Security and Special Nuclear Material Protection}

There are no special nuclear material protection requirements for this system.

\subsubsection{Special Installation Requirements}

There are no special installation requirements for this system.

\subsubsection{Reliability, Availability, and Preferred Failure Modes}

The IA system stays on line during the life of the project, and no unique maintenance activities are required during the CVDF three-year operating period. 


\subsubsection{Quality Assurance}

The IA system fabrication quality assurance/control program is based on the safety classification of the SSCs as detailed in the Safety Equipment List (HNF-SD-SNF-SEL-002) and the CVDF Master Equipment List (SNF-4148), and application of a graded approach as described in the Project Hanford Quality Assurance Program Description, HNF-MP-599.

\subsubsection{Miscellaneous}

A conceptual decontamination and decommissioning plan for the CVDF, as identified in the guidelines of DOE-STD-3009-94, Preparation Guide for U.S. Department of Energy Nonreactor Nuclear Facility Safety Analysis Reports, is included in HNF-SD-SNF-SAR-002. 


\subsection{SYSTEM DESCRIPTION}

\subsection{Configuration}

Each process bay is serviced by the IA system. The IA system components are described in the following section.

\subsubsection{Description of System, Subsystems, and Major Components}

4.1.1.1 System Description. The instrument air system is used to provide and distribute quality air throughout the CVDF. The compressed air system consists of duplex two-stage piston type compressors, a 250 -gal receiver tank, pressure control valve, compressed air dryer, filters, and desiccant instrument air dryers. For normal operation the instrument air system provides compressed air at a pressure of $100 \mathrm{lb} / \mathrm{in}^{2}$ gauge to the HVAC isolation dampers.

HVAC system isolation dampers fail closed if there is loss of electrical power. To ensure the process hood dampers on the process bay local HVAC exhaust and process vent system are reopened when standby power is activated and the local exhaust fan restarts, a safety-significant compressed air system is installed in each air line to each process bay hood isolation damper. The safety significant portion of the compressed air system in each process bay consists of an air tank, double check valves in the inlet air supply line to each compressed air tank, piping from the tank to the hood isolation damper actuator, and a pressure indicating gauge on the tank. Each compressed air tank reservoir has minimum capacity of 8.3 gal and is designed for a maximum pressure of $200 \mathrm{lb} / \mathrm{in}^{2}$ gauge. The normal operating pressure of $100 \mathrm{lb} / \mathrm{in}^{2}$ gauge provides sufficient air volume in the reservoir to complete four actuations of the isolation damper. Double check valves prevent loss of air to possible line breaks in the general service portions of the IA system and local air pressure indication is provided for the operator to monitor the tank pressure in each bay.

On loss of power, the solenoid valve will block back flow of air to the actuator for the process hood isolation damper and the damper will close. When standby power is activated, the solenoid valve energized and will reopen and air from the in-line safety significant compressed air reservoir will flow to the actuator to damper as required. The general service compressed air/instrument air system normally maintains pressure in the reservoirs. The reservoirs are isolated from the instrument air system by safety-significant check valves when process upsets occur, which result in loss of instrument air including loss of power. Periodic monitoring of the pressure in the tanks by the operators ensures capability for functional operation of the dampers upon loss of power.

4.1.1.1 Compressor and Drying Systems. Figure 4-2 shows a layout of the compressor and drying section of the IA system. The major components shown in Figure 4-2 are as follows.

- $\quad$ The two compressors (CA-CMP-5019) are two-stage, 1,020-rpm compressors with 7.5$\mathrm{hp}$, three-phase, 460 -volt motors, each with a pressure switch set at $145 \mathrm{psig}$ when on and 175 psig when off. The compressors are capable of $25.1 \mathrm{scfm}$ at $175 \mathrm{psig}$. 
- The tank (CA-TK-5019) is a 250-gal ASME national board tank with a safety valve. The tank is designed and ASME code-stamped for 200 psig; the safety valve is set at 200 psig. The tank has an automatic drain line that removes the condensate from the tank into a floor drain.

- The compressed air dryer (CA-DRY-5020) uses mechanical refrigeration to dry compressed air to a pressure dewpoint at $38^{\circ} \mathrm{F}$. The compressed air dryer is equipped with an automatic drain to discharge the condensate.

- The particulate pre-filter (CA-F-5022) is used to filter out any dry solid particles that may have come from the compressors or the air dryer. The particulate pre-filter is placed before the coalescing filter to remove larger size dry particles.

- The coalescing filter (CA-F-5023) is used to filter out any submicronic oil, water, and solid contaminants. The filter is designed to remove particles in the 0.3 to 0.6 micron range.

- $\quad$ Pressure control valve PCV-5006 reduces the pressure to 100 psig. Pressure relief valve SRV-5007 is set at 150 psig

- Desiccant compressed air dryer CA-DRY-5021 consists of two desiccant beds for drying the compressed air to a $-40^{\circ} \mathrm{F}$ dew point. The desiccant compressed air dryer is fully automatic and is equipped with a high-humidity alarm (XS-5009). The alarm will send a signal to the MCS if the humidity brings the dew point above $-40^{\circ} \mathrm{F}$.

- The particulate after-filter (CA-F-5024) is another filter placed in the line to capture any solid contaminants introduced into the compressed air line by the desiccant air dryer.

- $\quad$ Pressure transmitter PT-5008 and low pressure alarm PAL-5008 monitor the line pressure and provide an alarm to the MCS when the line pressure is to low. The low pressure alarm is set at TBD.

4.1.1.2 Distribution System. Figure 4-3 shows a layout of the distribution section of the IA system. The distribution system is made up of pressure control valves, check valves, isolation valves, and piping. The following paragraphs describe the second process bay distribution system. All process bays have the same layout.

- Line CA-001-GCS-1" delivers instrument quality air to isolation valve CA-V-201. The IA line then continues to check valve CA-CKV-201. 


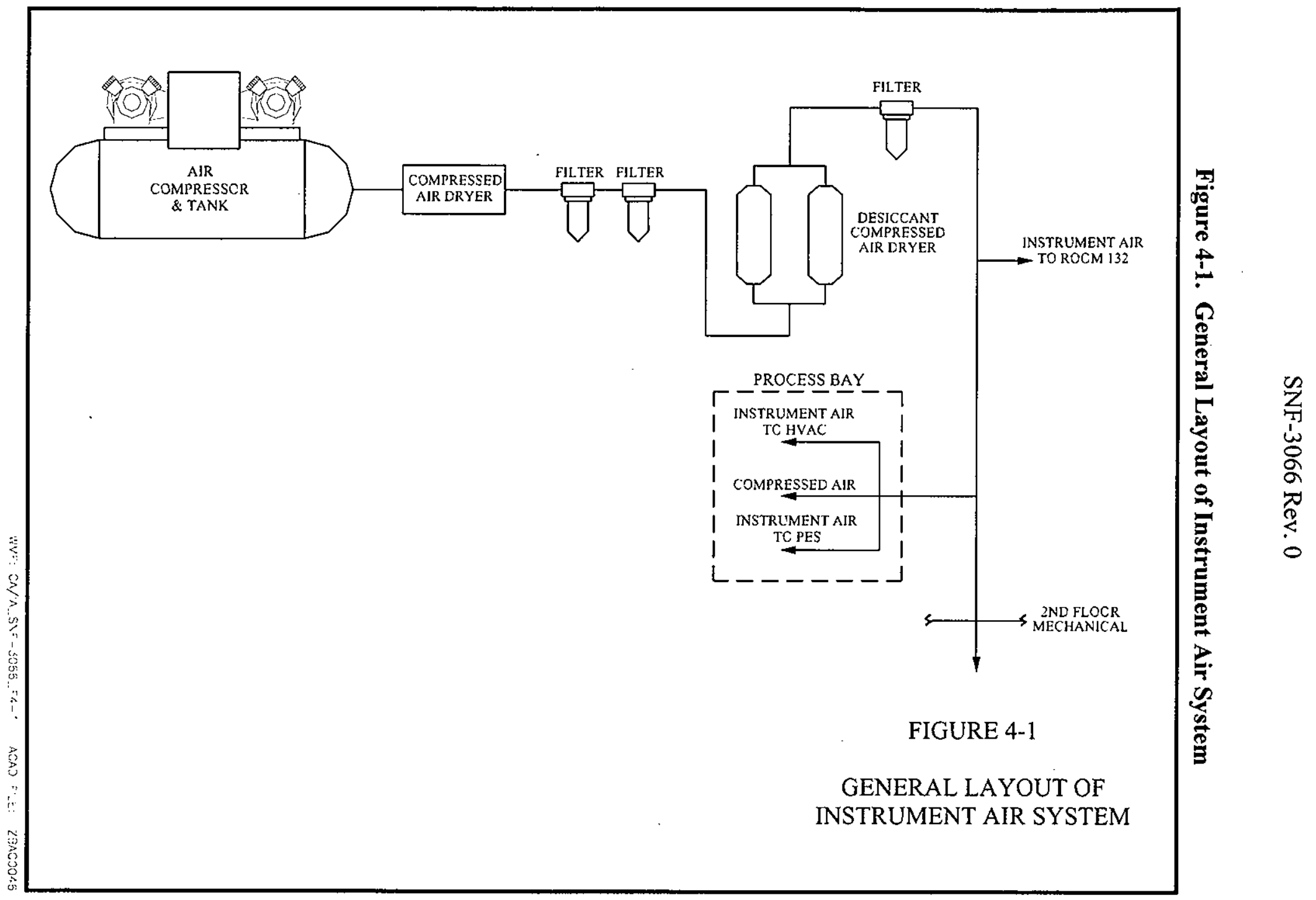




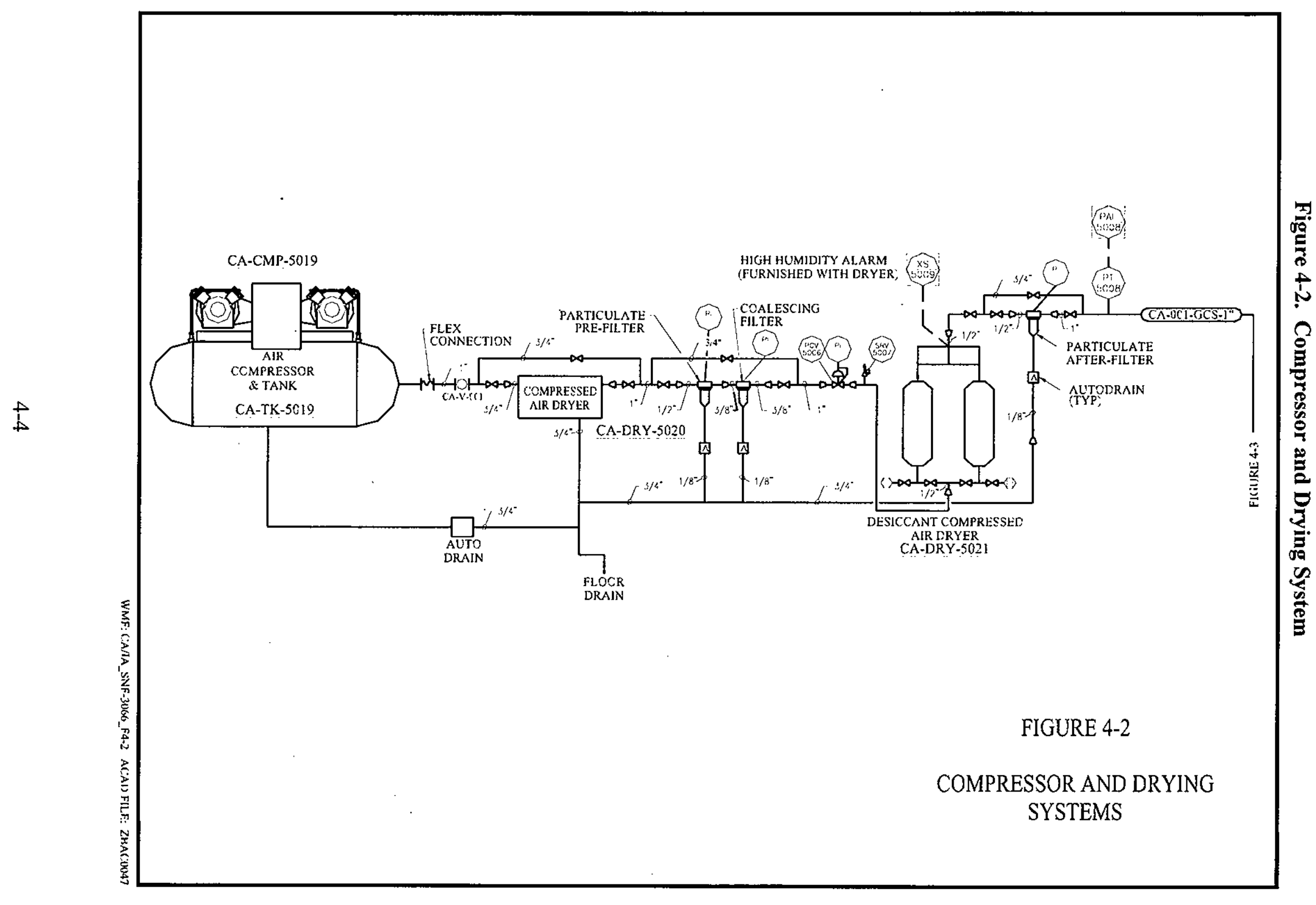


- The line enters a tee, and the branch line of the tee then separates into lines IA-202-ST$1 / 4$ " and CA-202-GCS- $1 / 2$ ". Line IA-202-ST- 1/4" enters isolation valve CA-V-202 and PCV-5010 (20 psig). PCV-5010 has a local pressure indicator attached. Line IA-202ST- $1 / 4$ " then provides IA to the HVAC controls, supply damper, and TV 8203. Line CAV-202-GCS- $1 / 2$ " provides compressed air to HVAC isolation dampers HVAC-DMP-8201 and HVAC-DMP-8203.

- The IA line comes through the tee and enters isolation valve CA-V-203. Line IA-201GCS-1" leaves CA-V-203 and provides IA to the process equipment skid at $100 \mathrm{psig}$.

- The distribution system provides IA to a few other systems. Line CA-001-GCS-1" provides air to isolation valve CA-V-004, which feeds line CA-009-GCS- 1/2". Line CA-009-GCS- $1 / 2$ " provides compressed air to HVAC isolation damper HVACDMP-8035 at 100 psig. Line CA-001-GCS-1" also provides IA to line CA-001-GCS- 1/2" and to line CA-101-GCS-1". Line CA-001-GCS- 1/2" flows through isolation valve CAV-002 and into check valve CA-CKV-001. Out of CA-CKV-001, line IA-001-GCS-1/2" provides IA to room 132, process water conditioning skid, at $100 \mathrm{psig}$. Line CA-101GCS-1" is fed from line CA-001-GCS-1" through isolation valve CA-V-101. Line CA101-GCS-1" is capped after CA-V-101.

The distribution system also provides compressed air to the second floor mechanical room through isolation valve $\mathrm{CA}-\mathrm{V}-003$. The compressed air is distributed to the HVAC system through line CA-002-GCS-1" and valves CA-V-005 through CA-V-011. The HVAC isolation dampers receive compressed air through lines CA-008-GCS- 1/2", CA-007-GCS- 1/2", CA-006GCS- $1 / 2 "$, CA-005-GCS- 1/2", CA-004-GCS-1", and CA-003-GCS- 1/2" at 100 psig. The HVAC control and TV air on line IA-002-ST- 1/2" is reduced to 20 psig by PCV-5009 before being sent. 
Figure 4-3. Distribution System

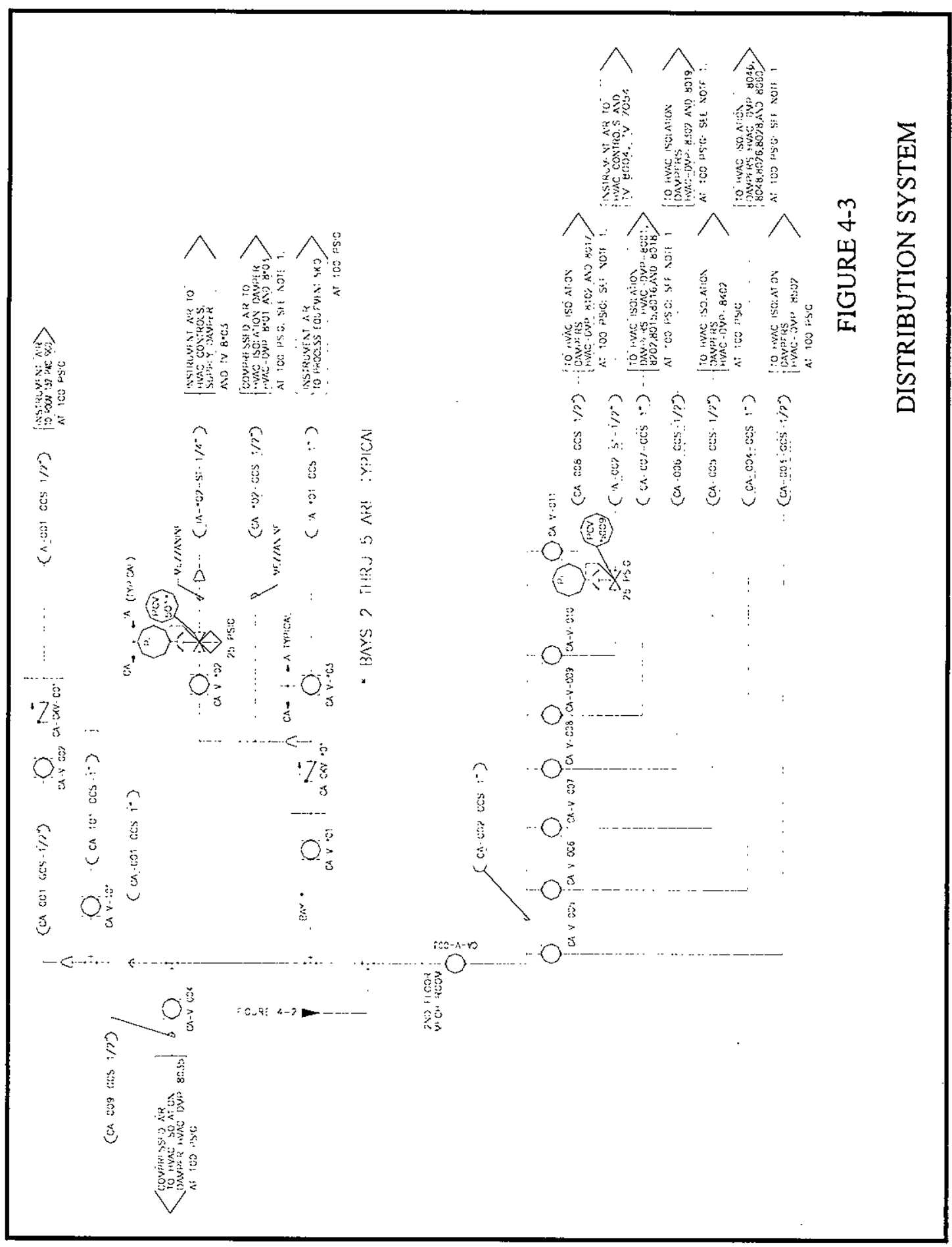

WV: CN/A_S. $=-3055 \% \%-3$ ACAD F"E: ZEACOOAB

\subsubsection{Boundaries and Interfaces}


The IA system has three different interfaces within each process bay. The IA system provides IA to the HVAC controls and supply dampers, and to the process equipment skid in each bay. The IA system also provides compressed air to the HVAC isolation dampers. The IA system interfaces with every air-operated valve in the CVDF. The HVAC system is described in SDD SNF-3081.

The IA system interfaces with the HVAC and other equipment outside of the process bays. The IA system provides compressed air to the HVAC isolation dampers (HVAC-DMP-8*01 and HVAC-DMP-8*03) in each process bay. IA interfaces with the temperature valves (TV-8*03) in each process bay. IA also interfaces with the process water conditioning skid in room 132, and interfaces with HVAC isolation damper (HVAC-DMP-8035). The following second floor mechanical room HVAC systems and temperature valves interface with the IA system: HVACDMP-8102, 8017, 8001, 8202, 8015, 8016, 8018, 8302, 8019, 8402, 8046, 8048, 8026, 8028, 8060 , and 8502 , TV-8004 and TV-7054. The process water system is described in SDD SNF3082.

The IA system interfaces with the CVD electrical normal and standby power systems. All electrical equipment is hardwired. The electrical equipment for the IA includes compressors, the compressed air dryer, and desiccant compressed air dryers, which are wired to the CVDF electrical power. The electrical system is described in SDD SNF-3075.

The IA system has limited interface with the MCS. The IA system provides two inputs to the MCS system (PAL-5008 and XS-5009). The MCS is described in SDD SNF-3090.

\subsubsection{Physical Location and Layout}

The IA system is located in the equipment/compressor room 120. The IA system is bounded by the compressor air intakes located in the equipment/compressor room 120 and the isolation valves before the interfaces with other systems. Refer to Figure 1-1 for a reference to the location of the IA system within the CVDF.

\subsubsection{Principles of Operation}

The IA system runs continuously in an automatic mode and provides four hours of compressed air in the event of downtime. The IA system provides dry, filtered air at approximately $100 \mathrm{psig}$ to operate pneumatic tools, cask/MCO seal ring assembly, and the cask transporter air-ride suspension. The IA system also provides air to operate the automatic-spring-return gas-operated valves in the process and safety systems, to inflate the MCO shield-seal ring bladder, and to purge the cask/MCO annulus following completion of the cold vacuum drying operation. The instrument air is provided at 20 psig to the HVAC system instruments. The IA system interfaces with several safety-class systems by providing pneumatic power to operate safety-class valves. These valves are designed to fail safe on loss of air.

The compressor and air tank operate on a cyclic pattern. Only one compressor at a time is required to be operating to supply air to the CVDF. The compressor turns off and on according 
to the demand of IA. The air tank allows the IA system to supply air during high demand operations at the CVDF. The compressors keep the pressure in the air tank between 145 psig and $175 \mathrm{psig}$. The compressors will turn on when the tank pressure drops to $145 \mathrm{psig}$ and turn off when the pressure reaches $175 \mathrm{psig}$. This operation ensures that air is available to the IA system at the proper pressure. The air tank is equipped with an automatic drain valve that drains the condensation from the air tank.

Compressed air dryer CA-DRY-5020 dries the compressed air to a dew point of $38^{\circ} \mathrm{F}$. The compressed air dryer uses refrigeration cooling to condense entrained moisture out of the air stream. Warm saturated air enters the heat exchanger where it is cooled by refrigeration causing water vapor to condense. A centrifuge separator and automatic drain removes condensate. The condensate is automatically discharged through a mechanical float drain trap. The compressed air dryer has a maximum working pressure of $175 \mathrm{psig}$ and an inlet temperature of $120^{\circ} \mathrm{F}$. The compressed air dryer also has a built-in oil and dirt filter to capture impurities.

The particulate pre-filter and the coalescing filter operate to remove the dry solid particles, oil aerosols, and water that may contaminate the IA system. The coalescing filter is designed to remove submicronic oil, water, and solid contaminants from compressed air. These filters are equipped with automatic drains to allow the contaminants to drain from the system.

Compressed air then enters the desiccant compressed air dryer to remove the remaining moisture. Compressed air enters the right desiccant tower through the inlet diverter valve and proceeds through the stainless steel diffuser screen. A few dehydration steps occur as the air flows over the desiccant bed. Initially, the lower portion of the bed removes gross amounts of water vapor. The process dew point begins to take form in the middle of the bed. The final dew point suppression occurs in the upper portion of the bed. The dehydrated compressed air then exits the bed through the diffuser screen into the outlet manifold. A percentage of the dry air is directed into the left desiccant bed for regeneration. The dry air purge enters the top of the left bed and flows down through the bed collecting moisture from the desiccant. The moisture is picked up by the air and exits to the atmosphere through a purge valve. The purge valve closes several seconds before the preset cycle inverts the beds and begins drying the process air in the left tower. The desiccant beds are equipped with a high humidity alarm that alerts the MCS if the humidity is above the preset condition.

The particulate after-filter is placed after the desiccant dryer to remove any solid contaminants that may have been introduced from the desiccant dryer. The filter is designed to remove all solid contaminants that remain to ensure instrument quality air.

\subsubsection{System Reliability}

The IA system is designed to operate continuously for the designed operational life of the facility (five years). The system is designed with a 250-gal air tank and redundant compressors. The IA system is designed to operate with only one compressor in service; the redundant compressor makes the system more reliable. The compressors, tank, filters, and dryers are located in equipment/compressor room 120 in the transfer corridor, isolated from personnel and equipment traffic. The piping that runs into each bay is at least five feet from the process bay floor and 
located under the mezzanine. The IA system is designed with a four-hour air supply if both compressors require downtime. The standby power supply will provide standby power for 24 hours after normal power is lost.

\subsubsection{System Control Features}

4.1.6.1 System Monitoring. The IA system contains two inputs to the MCS: a high humidity alarm (XS-5009) and a low-pressure alarm (PAL-5008). The MCS has no control functions of the IA system, only the monitoring of the two alarms (PAL-5008 and XS-5009).

4.1.6.2 Setpoints and Ranges. Nominal settings and system parameters for the IA system as based on initial design are as follows:

- $\quad$ Compressor maximum operating pressure is 175 psig with an operating range of 145 psig to 175 psig.

- $\quad$ Tank maximum pressure is 175 psig with an operating range of 145 psig to 175 psig.

- $\quad$ Pressure control valve PCV-5006 is set at 100 psig, and PCV-5009, PCV-5010, PCV$5011, \mathrm{PCV}-5012$, and PCV-5013 are set at 20 psig.

- $\quad$ Pressure relief valve SRV-5007 is set at 150 psig.

- $\quad$ Compressed air dryer CA-DRY-5020 has a maximum operating pressure of 175 psig and a maximum temperature of $120^{\circ} \mathrm{F}$.

- Desiccant compressed air dryer CA-DRY-5021 has a maximum operating pressure of 150 psig.

\subsection{Operations}

The CVDF operation is a batch process. The IA operates in conjunction with all the interface systems described in Section 4.1.2. For a detailed sequence of operations, see the operations manual, HNF-2356, and Appendix D of W-441-P003, The Fabrication and Procurement Specification for the Monitoring and Control System. Detailed operating steps are not presented here.

Test specifications will be developed to identify factory acceptance, construction acceptance, and pre-operational test procedures. Additional information relating to specifications and procedures will be added when available.

\subsubsection{Initial Configurations (Pre-startup)}

The initial configuration will be identified in the test specification. 


\subsubsection{System Startup}

Startup alignment and procedures will be identified in the test specification.

\subsubsection{Normal Operations}

Normal operation of the IA system is the continual operation of the IA system as described in Section 4.1.4. Operational procedures will be developed.

\subsubsection{Off-Normal Operations}

An off-normal operation would be the shutdown of the compressors and operation of the air tank. This could happen if unscheduled maintenance of the compressors is needed.

\subsubsection{System Shutdown}

To shut down the IA system, turn off the IA equipment, close the isolation valves discussed in Section 4.2.1, and release the pressure from the air tank.

\subsubsection{Safety Management Programs and Administrative Controls}

The safety management programs and administrative controls for this SDD will be integrated into the SNF Project Integrated Safety Management System.

\subsection{Testing And Maintenance}

The IA system is designed to operate through the design life of the equipment (five years) without regularly scheduled facility shutdowns for maintenance. System maintenance activities are limited to maintenance caused by failures. Additional maintenance activities and procedures can be scheduled if system surveillance, testing, or maintenance identifies additional requirements. All maintenance is performed under controlled procedures using approved (quality assurance-qualified) equipment and materials. Only spare parts meeting design criteria are procured and used. The equipment has been designed for efficient maintainability. The surveillance, testing, and maintenance of the system are achieved at minimum cost and level of support services per DOE Order 6430.1A, Section 1300-12.4.10.

\subsubsection{Temporary Configurations}

Not applicable.

\subsubsection{Technical Safety Requirement-Required Surveillances}

Not applicable.

\subsubsection{Non-Technical Safety Requirement Inspections, and Testing}


Surveillance and in-service inspections of equipment are made in accordance with the manufacturer's recommendations. As dictated by the equipment operating manuals, surveillance is incorporated into the IA system standard operating procedures. Operators are expected to report all occurrences to their supervisors who in turn initiate occurrence investigations. Accommodations have been made for both manual and electronic inspection of IA system equipment.

\subsubsection{Maintenance}

Maintenance features, including replacement procedures for valves and piping connected to the primary barrier, are designed so these activities can be carried out under heating, ventilation, and air conditioning inflow or isolation. Equipment and components have been located away from potentially contaminated areas, whenever practical, to reduce contact with contamination and minimize situations causing breach of containment. Modular design has been incorporated to facilitate change-out of systems requiring timely repair and/or special skills, and to reduce problems associated with equipment removal and repair. Commercial equipment, components, and parts are used wherever feasible to reduce procurement, maintenance, training, and inventory costs. Maintenance procedures will be developed.

\subsubsection{Equipment Calibration}

All equipment must be calibrated and recalibrated according to the manufacturer's recommended schedule and practice. Calibration and test connections will be provided to enable in-service testing and calibration when practical. 
SNF-3066 Rev. 0

Appendix A

Source Documents 


\section{INDUSTRY STANDARDS AND CODES}

ANSI/ASME B16 Standards series, 1996, Fittings, Flanges and Valves, American Society of Mechanical Engineers, New York, New York.

ANSI/ASME B16.5, 1996, Pipe Flanges and Flanged Fittings, American Society of Mechanical Engineers, New York, New York.

ANSI/ASME B16.10, 1992, Face to Face and End to End Dimensions of Valves, American Society of Mechanical Engineers, New York, New York.

ANSI/ASME B16.11, 1996, Forged Steel Fittings, Socket-Welding and Threaded, American Society of Mechanical Engineers, New York, New York.

ANSI/ASME B16.21, 1992, Nonmetallic Flat Gaskets for Pipe Flanges, American Society of Mechanical Engineers, New York, New York.

ANSI/ASME B16.25, 1997, Buttwelding Ends, American Society of Mechanical Engineers, New York, New York.

ANSI/ASME B16.34, 1996, Valves Flanged, Threaded, and Welding End, American Society of Mechanical Engineers, New York, New York.

ANSI/ASME B16.39, 1996, Malleable Iron Threaded Pipe Unions Classes 150, 250, and 300, American Society of Mechanical Engineers, New York, New York.

ANSI/ASME B18.2.1, 1992, Square and Hex Bolts and Screws Inch Series Including Hex Cap Screws and Lag Screws, American Society of Mechanical Engineers, New York, New York.

ANSI/ASME B31.9, 1996, Process Piping Code, American Society of Mechanical Engineers, New York, New York.

ANSI/ISA-S5.1, 1984 (1992), Instrument Symbols and Identification, Instrument Society of America, Research Triangle Park, North Carolina.

ANSI/ISA-S5.4, 1991, Instrument Loop Diagrams, Instrument Society of America, Research Triangle Park, North Carolina.

ANSI/ISA-S18.1, 1979 (1992), Annunciator Sequences and Specifications, Instrument Society of America, Research Triangle Park, North Carolina. 
ANSI/ISA-S20, 1981, Specification Forms for Process Measurement and Control Instruments Primary Elements and Control Valves, Instrument Society of America, Research Triangle Park, North Carolina.

ASME, 1995, Boiler and Pressure Vessel Code, American Society of Mechanical Engineers, New York, New York.

Section II, "Material Specifications, Welding Rods, Part C Electrodes, and Filler Metals"

Section VIII"Division I Rules for Construction of Pressure Vessels"

Section IX "Qualification Standard for Welding and Brazing Procedures, Welders, Brazers, and Welding and Brazing Operators"

ASTM A36, 1993, Standard Specification for Structural Steel, American Society for Testing and Materials, West Conshohocken, Pennsylvania.

ASTM A105, 1996, Standard Specification for Forgings, Carbon Steel, and for Piping Components, American Society for Testing and Materials, West Conshohocken, Pennsylvania.

ASTM A240, 1997, Standard Specification for Heat-Resisting Chromium and Chromium-Nickel Stainless Steel Plate, Sheet, and Strip for Pressure Vessels, American Society for Testing and Materials, West Conshohocken, Pennsylvania.

ASTM A269, 1996, Standard Specification for Seamless and Welded Austenitic Stainless Steel Tubing for General Service, American Society for Testing and Materials, West Conshohocken, Pennsylvania.

ASTM A276, 1997, Standard Specification for Stainless and Heat-Resisting Steel Bars and Shapes, American Society for Testing and Materials, West Conshohocken, Pennsylvania.

ASTM A307, 1993, Standard Specification for Carbon Steel Bolts and Studs, 60,000 psi Tensile Strength, American Society for Testing and Materials, West Conshohocken, Pennsylvania.

ASTM A312/312M, Rev. A, 1995, Standard Specification for Seamless and Welded Austenitic Stainless Steel Pipes, American Society for Testing and Materials, West Conshohocken, Pennsylvania.

ASTM A354, 1997, Standard Specification for Quenched and Tempered Alloy Steel Bolts, Studs and other Externally Threaded Fasteners, American Society for Testing and Materials, West Conshohocken, Pennsylvania.

ASTM A479, 1997, Standard Specification for Stainless and Heat-Resisting Steel Bars and Shapes for Use in Boilers and other Pressure Vessels, American Society for Testing and Materials, West Conshohocken, Pennsylvania. 
ASTM A480, 1997, Standard Specification for General Requirements for Flat-Rolled Stainless Heat-Resisting Steel Plate, Sheet, and Strip, American Society for Testing and Materials, West Conshohocken, Pennsylvania.

ASTM A500, 1993, Grade B Specification for Cold Formed, Welded and Seamless Carbon Steel Structural Tubing in Rounds and Shapes, American Society for Testing and Materials, West Conshohocken, Pennsylvania.

ASTM A563, 1996, Standard Specification for Carbon and Alloy Steel Nuts, American Society for Testing and Materials, West Conshohocken, Pennsylvania.

AWS-D1.1, 1996, Structural Welding Code--Steel, American Welding Society, Miami, Florida.

IEEE-603, 1991, Standard for Design Qualification of Safety Systems for Nuclear Power Generating Stations, Institute of Electrical and Electronics Engineering, Piscataway, New Jersey.

NEMA 250, 1997, Enclosures for Electrical Equipment (1000 V maximum), National Equipment Manufacturers Association, Roslyn, Virginia.

SNT-TC-1A, 1996, Recommended Practice, American Society of Nondestructive Testing, Columbus, Ohio.

TEMA, 1982, Heat Exchangers Mechanical Standards, Tubular Exchanger Manufacturers Association, Tarrytown, New York.

\section{GOVERNMENT DOCUMENTS}

10 CFR 830.120, "Quality Assurance Requirements," Code of Federal Regulations, as amended.

10 CFR 835, "Occupational Radiation Protection," Code of Federal Regulations, as amended.

29 CFR 1910.120, "Occupational Safety and Health Standards," Code of Federal Regulations, as amended.

DOE-STD-1021, Natural Phenomena Hazards Design and Evaluation Criteria for Department of Energy Facilities, DOE Standard 1021, U.S. Department of Energy, Washington, D.C.

DOE-STD-3009-94, 1994, Preparation Guide for U.S. Department of Energy Nonreactor Nuclear Facility Safety Analysis Reports, U.S. Department of Energy, Washington, D.C.

Ecology, EPA, and DOE, 1994, Hanford Federal Facility Agreement and Consent Order, as amended, Washington State Department of Ecology, U.S. Environmental Protection Agency, and U.S. Department of Energy, Olympia, Washington. 
G-10 CFR 835/B2-Rev.0, Implementation Guide for Use with Title 10, Code of Federal Regulations, Part 835 Occupational Radiation Protection.

\section{SPENT NUCLEAR FUEL PROJECT DOCUMENTS}

HNF-2356, 1998, Spent Nuclear Fuel Project Cold Vacuum Drying Facility Operations Manual, Rev. 1, DE\&S Hanford, Inc., Richland, Washington.

HNF-3553, Annex B, 1999, Safety Analysis Report for the Cold Vacuum Drying Facility, Phase 2, Supporting Installation of Processing Systems, Rev. 4, Fluor Daniel Hanford, Inc., Richland, Washington.

HNF-SD-SNF-DR-003, 1998, Multi-Canister Overpack Design Report, Rev. 3, Fluor Daniel Hanford, Inc., Richland, Washington.

HNF-SD-SNF-DRD-002, 1998, Cold Vacuum Drying Facility Design Requirements, Rev. 4, Fluor Daniel Hanford, Inc., Richland, Washington.

HNF-SD-SNF-SEL-002, 1998, Spent Nuclear Fuel Project Cold Vacuum Drying Facility Safety Equipment List, Rev. 6, Fluor Daniel Hanford, Inc., Richland, Washington.

HSRCM-1, 1995, Hanford Site Radiological Control Manual, Rev. 2, Westinghouse Hanford Company, Richland Washington.

SNF-3001, 1998, CVDF Data and Calculation Matrix Tracking List, Rev. A, DE\&S Hanford, Inc., Richland, Washington.

SNF-3089, 1998, Cold Vacuum Drying Facility Security System Design Description, Rev. A, DE\&S Hanford, Inc., Richland, Washington.

SNF-AP-5-006, ALARA Goals, Training, and Control Level Administration, DE\&S Hanford, Inc., Richland, Washington.

SNF-AP-5-012, Radiological ALARA Work Planning Process, DE\&S Hanford, Inc., Richland, Washington.

SNF-AP-5-013, Radiological ALARA Process, DE\&S Hanford, Inc., Richland, Washington. 
SNF-3066 Rev. 0

\section{Appendix B}

System Drawings

B-1 
SNF-3066

Revision 0

June 7, 1999

Complete sets of drawings are located with the Spent Nuclear Fuel Project files for the CVDF project.

Drawing Number

H-1-82160

H-1-82161

H-1-82222

$\mathrm{H}-1-83978$
Title

Cold Vacuum Drying Facility P\&ID Legend

Cold Vacuum Drying Facility Process Equipment Skid

P\&ID MCO/Cask Interface

Cold Vacuum Drying Facility Mechanical Utilities

Compressed \& Instrument Air P\&ID

Cold Vacuum Drying Facility Generator Building Electrical

One-Line Diagram
Sheet

Number

1

1

2

1 
SNF-3066 Rev. 0

\section{Appendix C}

System Procedures 
SNF-3066 Rev. 0

Operating and maintenance procedures will be developed. 


\section{DISTRIBUTION SHEET}

\begin{tabular}{|c|c|c|c|c|c|}
\hline \multirow{2}{*}{$\begin{array}{l}\text { To } \\
\text { Distribution }\end{array}$} & \multirow{2}{*}{\multicolumn{3}{|c|}{$\begin{array}{l}\text { From } \\
\text { Technical Integration }\end{array}$}} & \multicolumn{2}{|l|}{ Page 1 of 1} \\
\hline & & & & \multicolumn{2}{|c|}{ Date June 14,1999} \\
\hline \multirow{2}{*}{\multicolumn{4}{|c|}{$\begin{array}{l}\text { Project Title/Work OrderEDT-626313 } \\
\text { SNF-3061, SNF-3066(SNF-3067) SNF-3072, SNF-3073, SNF-3074, } \\
\text { SNF-3077( SNF-3078, SNF-3079, SNF-3080, SNF-3081) on EDT.626311 }\end{array}$}} & \multirow{2}{*}{\multicolumn{2}{|c|}{$\begin{array}{l}\text { EDT No. } 626308,763 \\
\text { ECN No. NA }\end{array}$}} \\
\hline & & & & & \\
\hline Name & MSIN & $\begin{array}{l}\text { Text } \\
\text { With All } \\
\text { Attach. }\end{array}$ & Text Only & $\begin{array}{l}\text { Attach./ } \\
\text { Appendix } \\
\text { Only }\end{array}$ & $\begin{array}{l}\text { EDT/ECN } \\
\text { Only }\end{array}$ \\
\hline W. C. Alaconis & R3-86 & $\mathrm{X}$ & & & \\
\hline L. L. Blehm & X3-86 & $\mathrm{X}$ & & & \\
\hline K. A. Boes & R3-86 & $\mathrm{X}$ & & & \\
\hline J. R. Brehm & $\mathrm{R} 3-86$ & $\mathrm{X}$ & & & \\
\hline C. S. Haller & R3-11 & $\mathrm{X}$ & & & \\
\hline L. C. McKenzie & S2-45 & $\mathrm{X}$ & & & \\
\hline S. L. Mischke & R3-86 & $\mathrm{X}$ & & & \\
\hline C. C. Pitkoff & R3-86 & $\mathrm{X}$ & & & \\
\hline CVD Project File & R3-86 & $X$ & & & \\
\hline SNF Project File & R3-11 & $\mathrm{X}$ & & & \\
\hline
\end{tabular}

